\title{
Drilling for the Archean Roots of Life and Tectonic Earth in the Barberton Mountains
}

\author{
by Eugene G. Grosch, Nicola McLoughlin, Maarten de Wit, and Harald Furnes
}

doi:10.2204/iodp.sd.8.03.2009

\section{Introduction}

In the Barberton Scientific Drilling Program (BSDP) we successfully completed three drill holes in 2008 across strategically selected rock formations in the early Archean Barberton Greenstone Belt, South Africa. This collaborative project's goal is to advance understanding of geodynamic and biogeochemical processes of the young Earth. The program aims to better define and characterize Earth's earliest preserved ocean crust shear zones and microbial borings in Archean basaltic glass, and to identify biogeochemical fingerprints of ancient ecological niches recorded in rocks. The state-of-the-art analytical and imaging work will address the question of earliest plate tectonics in the Archean, the $\delta 18 \mathrm{O}$ composition, the redox state and temperature of Archean seawater, and the origin of life question.

The BSDP project serves as a first phase towards a large-scale deep drilling project which will also encompass the development of a local Earth science research and education center. During the period July-August 2008, a first phase of drilling yielded three boreholes with a total of $800 \mathrm{~m}$ of core with 99\% core recovery in the early Archean Barberton Greenstone Belt (BGB), South Africa. Five decades of scientific research on the 3.5-3.1-Ba-old BGB has established the mountain ranges of Barberton as a world heritage site and a focus for international scientists interested in early Earth processes. The rocks around Barberton are unique in that they represent relatively intact and undisturbed remnants of preserved ancient seafloor and continental crust that have largely escaped tectonometamorphic reworking since the time they formed (Schoene et al., 2008).

Outstanding questions about early Earth-as well as Earth systems and linkages between physical, chemical, and biological processes operating within and on the early Earth-include the following areas of interest:

- $\quad$ plume-driven versus plate-tectonic-driven mechanisms for the early Archean

- Earth's early magnetic field and exogenous influx from space

- volcanology, origin of komatiites, and thermal gradients on early Earth

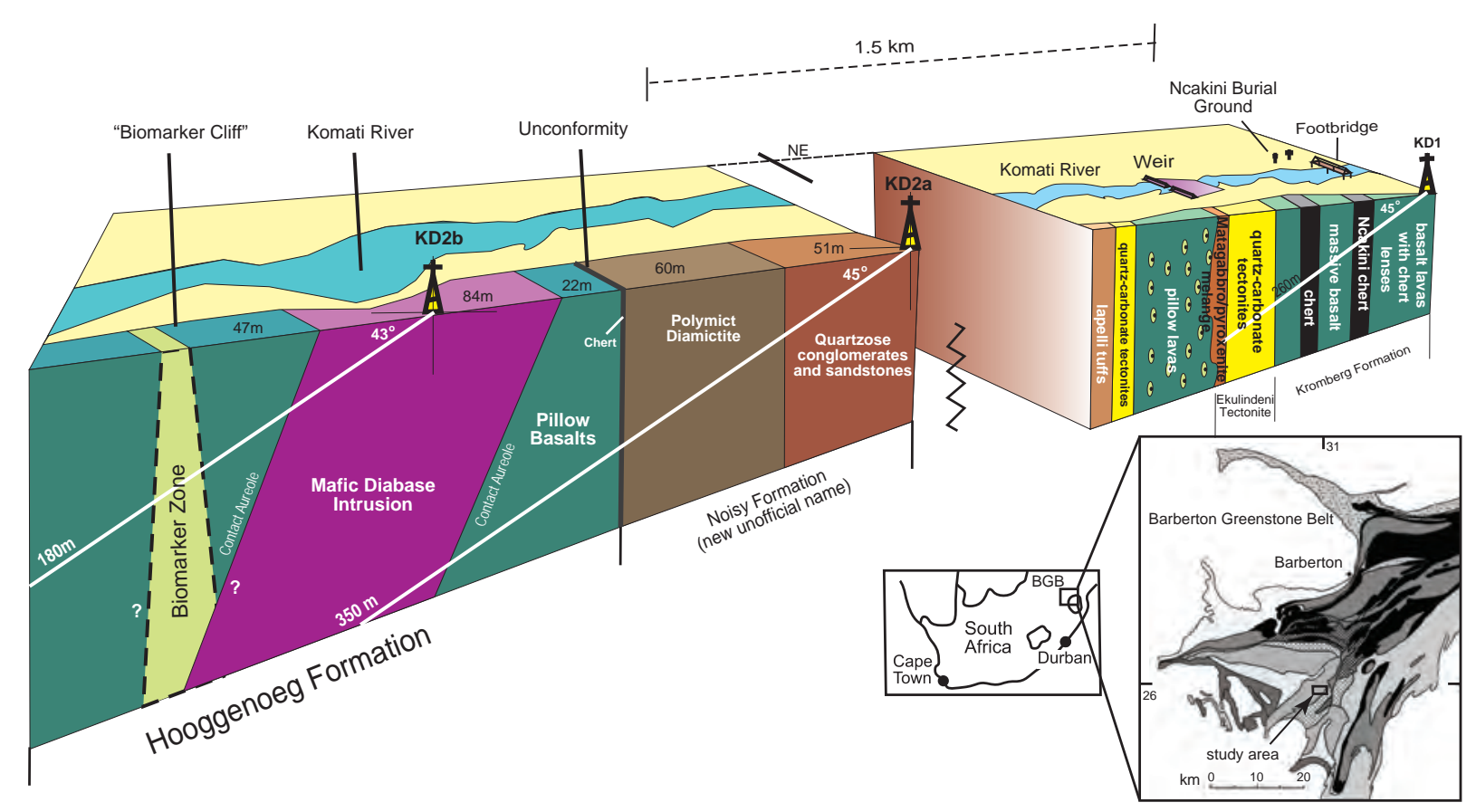

Figure 1. Three-dimensional block diagram with simplified geology depicting the positions and shallow drilling angles at drill sites KD1, KD2a, and KD2b and location maps of the study area with South Africa and simplified geology of Barberton Greenstone Belt (BGB map modified from Kareem, 2005). 
- chemical, structural, and tectonic make-up of the oldest greenstone belts

- crustal and mantle fluid processes, chemistry of ancient seawater composition

- climate and atmospheric conditions at 3.4-3.5 Ga

- origin of life and early life-sustaining environments

Addressing these topics using surface samples has, however, been plagued by a number of complications related to limited exposure and secondary processes like weathering.

Diamond core drilling, which retrieves fresh, representative samples from depth at strategic locations, has the advantage of providing continuous information with depth, and avoiding a number of complexities related to surface processes.

\section{Geological Background and Drill Site Locations}

The BGB forms part of the easternmost margin of the Kaapvaal Craton as a NE-SW trending tectono-metamorphic belt. Traditionally, rocks in the southern part of the belt have been ascribed to the 3.2-3.5 Ga Swaziland Supergroup, which in turn has been further subdivided into the Onverwacht, Fig Tree, and Moodies Groups (Viljoen and Viljoen, 1969; Brandl et al., 2006). Drilling was aimed at focusing on the mostly tholeiitic basalts of the 3.47-3.44-Ga mid-upper Onverwacht Group of the Swaziland Supergroup in the southwesternmost BGB (Fig. 1). Drill sites are located in the Songimvelo Nature Reserve, near Ekulindeni (Kromdraai). The exposed rocks include the Mendon, Kromberg, and Hooggenoeg Formations of the Onverwacht Group.

The first hole (KD1, S26 $02^{\prime} 15.3^{\prime \prime}, \mathrm{E} 31^{\circ} 00^{\prime} 00.0^{\prime \prime}$, total depth of $261 \mathrm{~m}$ ) allowed sampling into the Upper Kromberg Formation, a section of pillow lavas and sheet flow with interlayered cherts and chert xenoliths that overlies an enigmatic early carbonated and silicified oceanic shear zone known as the Ekulindeni Shear Zone. Drilling stopped in pyroxenitic units just beyond a carbonated shear zone. Studies on core samples will allow definition of the chemical alteration and microbial activities from an Archean marine bottom-surface into its underlying sub-surface fault zones. Results will also help to reconstruct the chemical composition and temperature of the associated seawater.

The second and third holes (KD2a, S26 01'50.0", $\mathrm{E} 30^{\circ} 59^{\prime} 32.6^{\prime \prime}$ and $\mathrm{KD} 2 \mathrm{~b}, \mathrm{~S} 26^{\circ} 01^{\prime} 25.3^{\prime \prime}, \mathrm{E} 30^{\circ} 59^{\prime} 16.6^{\prime \prime}$, total depths of $350 \mathrm{~m}$ and $180 \mathrm{~m}$, respectively) are located about $1.5 \mathrm{~km}$ farther NE along the Komati river on a flat open river terrace. The main objective of these holes was to drill across a basal unconformity in the Hooggenoeg Formation between a set of subaerial siliciclastics consisting of diamictites, conglomerates, and sandstones and underlying basaltic

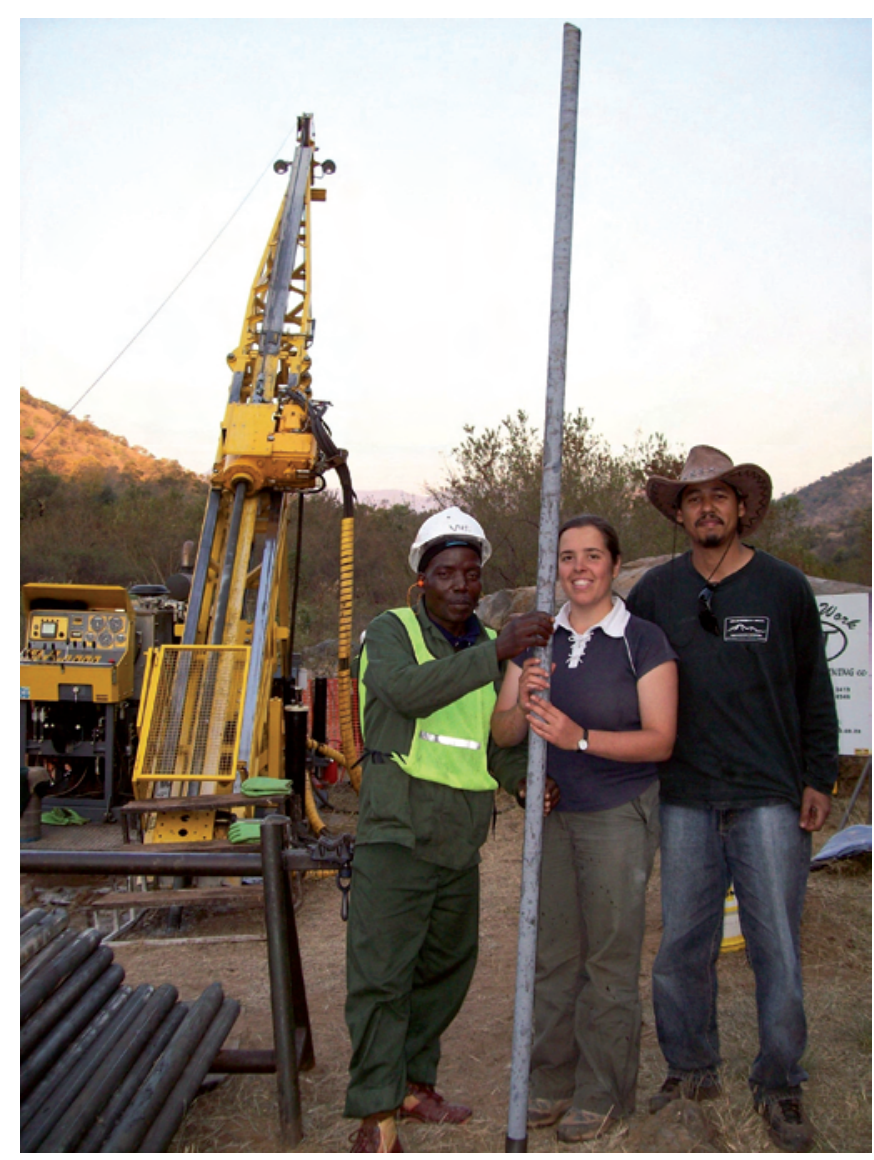

Figure 2. Drill rig aligned and set to drill at the shallowest possible angle $\left(45^{\circ}\right)$ relative to the dip and dip direction of the steep near-vertical orientation of the geological units along the Komati River. The $>3-\mathrm{m}$-long rod is composed of basalt or diamictites.

pillow lavas with interbedded cherts. Although these conglomerates were formerly placed in the Hooggenoeg Formation by Viljoen and Viljoen (1969), ongoing geological mapping in the area has lead to a revised stratigraphy (de Wit et al., in prep.). The pillow lava basalts in the Hooggenoeg Formation contain early Archean biomarkers or ichnofossils described by Furnes et al. (2004), in the type area known as the "Biomarker Cliff". Field and preliminary core observations suggest that in this site the top of the pillow lava pile was exposed to the Archean atmosphere at the unconformity. To avoid an 84-m-thick mafic/diabase intrusion about $22 \mathrm{~m}$ away from the unconformity, we relocated the drill rig for a third hole (KD2b) $172 \mathrm{~m}$ further north (Fig. 1). Drilling at $\mathrm{KD} 2 \mathrm{~b}$ intercepted the type section for the biogenic structures that occur in pillow lava margins and typify Earth's 3.4-Ga oceanic environments, including an early hydrothermal ocean-floor-type metamorphic overprint (Furnes et al., 2004). This part of the section will allow the physio-chemical conditions of the biological communities in the pillow margins and their preservation window to be better defined.

\section{Drilling Methods}

The drill rig was oriented perpendicular to the bedding or structural orientation of the lithological units, using the average strike and dip readings of rock outcrops at the site. 
Given the steep, generally vertical orientation of the geologic units, drilling for all three boreholes was carried out at the shallow angle of about $45^{\circ}$ and a drilling direction towards $320^{\circ}$ to $340^{\circ}$ (Fig. 2). Drilling at shallow angles raised a number of difficulties, including borehole wall collapses in the alluvial overburden. Due to frictional drag of the inner tube on the inside of the drill stem rods, the elapsed time between runs increased significantly as a consequence of the flat angle. The overshot instrument attached to the wireline for lowering the innertube down the hole was modified with a heavy metal rod weight to overcome frictional energy downhole to shorten down time and to facilitate efficient latching of the innertube onto the core barrel. The potentially delicate nature of bio-textures and chemical biomarker (carbon) signatures to be encountered made it vital not to alter the original Archean chemistry of the drilled rock. Furthermore, since data on the redox state of the Archean atmosphere and seawater composition is one of the analytical goals, reducing oxidation was imperative. Therefore, a number of steps were taken during the drilling project to ensure that the original rock chemistry remained as intact as possible.

- Only clean water was used as drilling mud.

- A clean drill rig was used and repeatly washed, and the site was kept clean of potential contaminants including smoke at all times.

- Only one person handled, washed, and dried all core immediately after retrieval.

- Cores were packed in wooden boxes with wood chips for support during shipping.

Core recovery for all three holes was typically above $98 \%$ providing up to 3-m rods of core (Fig. 2). Only in the case of intercepting the first chert horizon, namely the "Footbridge Chert" in KD1, did core recovery temporarily drop to $92 \%$ due to partial fracturing of the chert. Initial stages of each hole involved emplacement of $\mathrm{HQ}$ (63.5-mm diameter) size metal casing to stabilize the hole.

Water flow rate downhole generally varied at 30-33 L $\min ^{-1}$. Optimum revolutions per minute were around 580, typical for basalts at a torque of around $3 \mathrm{kN}$. Given the flat $45^{\circ}$ angle, the weight on the bit for the drill rig was adjusted to around $2-2.5 \mathrm{kN}$ using a soft matrix NQ corebit (47.6-mm diameter). The very hard chert horizons were cored at $450 \mathrm{rpm}$. A core orientation tool was used to fix the orientation for paleomagnetic studies on basalts.

\section{Preliminary Results}

Core $\log$ data from KD1 (total length $261 \mathrm{~m}$ ) records about $54.5 \mathrm{~m}$ of basalts from the Mendon Formation before the top of the Kromberg Formation was intercepted (Fig. 3). The section of drill core representing this formation includes two major chert units of about $12 \mathrm{~m}$ each in an 83-m-thick section of variably metasomatized and silicified massive intrusives and lava flows. The first of these chert units appears to record an 


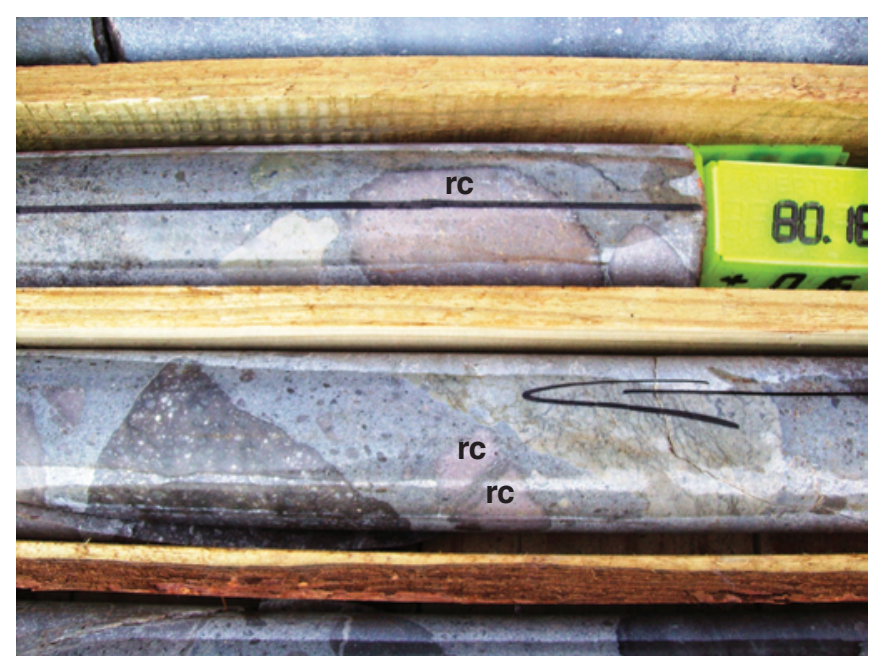

Distinct chemical weathering rim around light pink rhyolitic clasts ( $r c$ ) possibly recording weathering conditions and/or redox conditions on the early Earth's surface.

upper 2.5-m-thick oxidized horizon, followed by an $8.5-\mathrm{m}$ lower part consisting of black massive occasional white banded chert containing sulfides (implying a more reduced environment). The second chert unit was intercepted at a depth of about $115 \mathrm{~m}$ below surface; it occurs at the center of a 30-m-wide zone of highly silicified basalt that is generally associated with a number of discontinuous black chert lenses and veins. Near the end of KD1, a 20-m-thick zone occurs with thin black chert veins and consists of carbonate and quartz bands and veins in a matrix of dark green fuchsite (Cr-muscovite), chlorite, and magnetite. In surface outcrop this zone is as thick as $67 \mathrm{~m}$, and it is adjacent to a 72-m-thick unit of highly foliated metapyroxenite. It is currently interpreted to represent a remnant component of an early oceanic shear zone. The carbonate-quartz tectonite zone, as seen in the drill core, is less than one-third of its thickness on surface, indicating discontinuous and variable thickness. Drilling stopped in a metapyroxenitic unit consisting of a melange of metagabbros and pillow basalt screens for about $17 \mathrm{~m}$ beyond the end of the carbonate-quartz zone. Micro- to nano-scale analysis of the rock units in KD1 will allow comparison of various potential ecological niches across an Archean seafloor environment into deeper underlying sub-seafloor tectonite zones. Such a comparison has not been previously carried out. Carbonaceous cherts in the upper and lower parts of KD1-representing marine seafloor and hydrothermal cherts, respectively-are the primary analytical target in the search for early life microtextures and chemical fingerprints in KD1. These rocks will be investigated using laser Raman microspectroscopy and bulk rock geochemical analysis. Calcite-quartz extensional veins/bands in the lower tectonite zone will be analyzed for their $\delta 180$ composition to determine hydrothermal seawater fluid temperatures and water-rock ratios. These results will be integrated with in situ stable isotope and synchrotron $\mathrm{X}$-ray analyses of individual fluid inclusions in the lower tectonite zone, combined with a micro-structural fabric analyses of deformed rocks. High-resolution Secondary Ion
Microprobe Analyses of various sulphide generations present throughout KD1 aims to investigate mass-dependent and possible mass-independent sulphur isotope fractionation as a geochemical tool to identify microbial interactions and improve our understanding of the early Earth's sulfur cycle.

Drill hole KD2a penetrated a basal unconformity at around $126 \mathrm{~m}$ below surface, between a lower marine section of pillow lavas and interbedded cherts that are abruptly overlain by subaerial diamictites, conglomerates, and sandstones. In the drill core, clasts in diamictite units directly above the unconformity are poorly sorted, polymictic in composition, and generally angular giving the rocks a breccia-like appearance suggestive of glacial diamictites. Many of the clasts, particularly those of the rhyolitic and dacitic composition, display a prominent weathering halo or chemical alteration rim (Fig. 4). Preliminary measurement of clast size in the core indicates that the entire unit coarsens upward. Overlying these 'diamictites' are more typical fluvial facies, conglomerates, and sandstones. However, pronounced soft sediment deformation features are also present and may suggest an offshore marine turbidite facies origin. A sedimentological provenance study involving a detailed documentation of the petrological characteristics of the clasts, U-Pb dating of detrital zircons from selected depths in the core, and reconstructing a chemical weathering profile will aim at understanding of the depositional environment(s) of these enigmatic sediments and possibly constraining the atmospheric conditions on the Earth's surface at $\sim 3.45 \mathrm{Ga}$. The lower part of drill hole KD2a penetrated a section of thermally altered pillow basalts in a metamorphic contact aureole and ended in a medium-grained mafic intrusive at a depth of $350 \mathrm{~m}$.

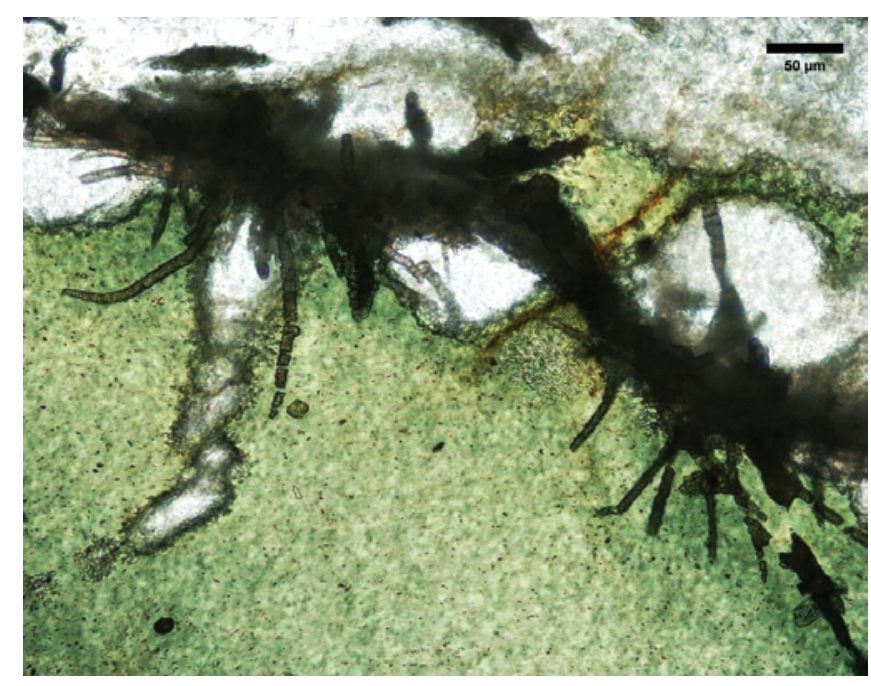

Photomicrograph of microbial biotextures in a surface sample of inter-pillow breccia from the Hooggenoeg Formation of the Barberton Greenstone Belt. The meta-volcanic glass comprises a greenschist facies assemblage of chlorite and quartz with titanite-filled tubular textures. These are curvilinear and unbranched, and they radiate from a central band of microcrystalline titanite. Some taper towards their ends and are segmented by cross-cutting chlorite. These textures are interpreted to be mineralized tunnels created by microbes that etched volcanic glass on the Archean sub-seafloor. This is a composite z-stacked high-resolution image showing tubes at different focal depths. 
The third hole, KD2b, intercepted at depth the "Biomarker Zone" originally described in surface outcrop by Furnes et al. (2004). Detailed petrographic work on surface samples from this zone has shown a range of morphological types of ichnofossils (McLoughlin et al., 2007; see also Fig. 5). The recent in situ $\mathrm{U}-\mathrm{Pb}$ dating of titanite infilling the microbial ichnofossils has revealed an Archean age (Fliegel et al., 2008). Pillow lavas in the drill core of KD2b will be investigated for early Archean ichnofossils from a depth of around $130 \mathrm{~m}$ onwards to further investigate morphological diversity and antiquity of the bioalteration textures by applying state-of-the-art analytical and imaging techniques (e.g., Raman spectroscopy, X-ray synchrotron imaging). A detailed study of the continuous drill core section recovered from depth in KD2b aims to reconstruct the spatial distribution of these microbial ichnofossils with depth through an ancient oceanic lithosphere. In addition, we aim to determine the preservation conditions of the biosignatures and the prevailing life-sustaining hydrothermal conditions that existed in the early oceanic crust.

KD2b also penetrated thermally altered pillow basalts in a metamorphic contact aureole around the northern margin of the mafic intrusion that will be used as a thermal and reversal test for paleomagnetic studies. To date, only volcanic rocks of late Archean age $(2.7 \mathrm{Ga})$ have yielded detailed paleomagnetic signatures, and we anticipate that this Barberton drill core will provide new insights into the strength of the much earlier $\sim 3.45 \mathrm{Ga}$ Archean magnetic field and the size of the young Earth's inner core.

\section{Future Plans for Drilling in Barberton}

The present drilling project serves as a preliminary stage for a more ambitious super-deep drilling project to penetrate one of two ancient crustal-scale suture zones in the BGB. A magneto-telluric transectacross the BGB has been conducted over the period March-May 2009 to start identifying the target zone. This will be followed by a seismic survey and an on-site ICDP workshop to plan a proposal for deep drilling. In addition, we plan to establish an advance drilling technology school and develop a rural science education center linked to a world class 'Early Earth' museum near this drill site.

\section{Acknowledgments}

We thank Annelize Steyn, Johan Eksteen, Shane Plumkel, and Property Mokoene from the Mpumalanga Tourism and Parks Agency (MTPA), Songimvelo Nature Reserve, South Africa for their support and valuable environmental advice prior to and during the drilling operation. Thanks are also due to Fred Daniel of Nkomazi Wilderness for his continued support of our Barberton research. This joint project was funded by the Center for Geobiology (Norwegian Centre of Excellence) at the University of Bergen, Norway and the Africa Earth Observatory Network (AEON) at the University of Cape Town, South Africa. Drillers in Training (South
Africa) and Atlas Copco Exploration Products Africa are thanked for their technical support. This is an AEON contribution number 58 .

\section{References}

Brandl, G., Cloete, M., and Anhaeusser, C.R., 2006. Archaean greenstone belts. In Johnson, M.R., Anhaeusser, C.R., and Thomas, R.J. (Eds.), The Geology of South Africa, Johannesburg and Pretoria (Geological Society of South Africa, and Council for Geosciences), 9-56.

Fliegel, D., McLoughlin, N., Simonetti, A., de Wit, M., and Furnes, H., 2008. In situ dating of the oldest morphological traces of life on Earth. Eos Trans. AGU, 89(53) Fall Meet. Supplement, Abstract P51A-1395.

Furnes, H., Banerjee, N.R., Muehlenbachs, K., Staudigel, H., and de Wit, M., 2004 Early life recorded in Archean pillow lavas. Science, 304:578-581, doi:10.1126/science.1095858.

Kareem, K., 2005. Komatiites of the Weltevreden Formation, Barberton Greenstone Belt, South Africa: implications for the chemistry and temperature of the Archean mantle. PhD dissertation, The Department of Geology and Geophysics of the Louisiana State University, $227 \mathrm{pp}$.

McLoughlin, N., Brasier, M.D., Wacey, D., Green, O.R., and Perry, R.S., 2007. On biogenicity criteria for endolithic microborings on early Earth and beyond. Astrobiology, 7(1):10-11, doi: 10-26. doi:10.1089/ast.2006.0122.

Schoene, B., Bowring, S.A., and de Wit, M.J., 2008. Assembly and stabilization of the eastern kaapvaal craton: a structuralthermochronological perspective. Tectonics, 27:TC5010, doi:10.1029/2008TC002267, 2008 (27 pgs).

Viljoen, M.J., and Viljoen, R.P., 1969. The geology and geochemistry of the lower ultramafic unit of the Onverwacht Group and a proposed new class of igneous rocks. Geol. Soc. S. Afr., Sp. Pub., 2:55-86.

\section{Authors}

Eugene G. Grosch and Maarten de Wit, Africa Earth Observatory Network (AEON) and the Department of Geological Sciences, University of Cape Town, Rondebosch 7700, South Africa, e-mail: geogene@gmail.com.

Nicola McLoughlin and Harald Furnes, Department of Earth Science and Centre for Geobiology, University of Bergen, Allegaten, 41, N-5007 Bergen, Norway.

\section{Related Web Links}

http://www.aeon.uct.ac.za/

http://www.uib.no/geobio/en/

http://www.uib.no/geobio/en/public-outreach/fieldactivities

\section{Figure and Photo Credits}

Fig. 1, 3: Eugene G. Grosch (AEON, Cape Town)

Fig. 2: Photo by Harald Furnes (CGB, Bergen)

Fig. 4: Photo by Eugene G. Grosch (AEON, Cape Town)

Fig. 5. Photomicrograph by Nicola McLoughlin (CGB,

Bergen) 